\title{
Phenotypic Dispersion of Landrace Lima Bean Varieties Using Multidimensional Scaling
}

\author{
Priscila A. Barroso ${ }^{1}$, Artur M. Medeiros ${ }^{1}$, Natanael P. S. dos $\operatorname{Santos}^{1}$, Dyane C. Q. Silva ${ }^{2}$, \\ Silvokleio da C. Silva ${ }^{2} \&$ Regina L. F. Gomes ${ }^{3}$ \\ 1 Laboratório de Melhoramento Genético e Análise de Dados, Universidade Federal do Piauí, Campus \\ Professora Cinobelina Elvas, Bom Jesus, Piauí, Brazil \\ ${ }^{2}$ Laboratório de Genética e Conservação de Germoplasma, Universidade Federal do Piauí, Campus Professora \\ Cinobelina Elvas, Bom Jesus, Piauí, Brazil \\ ${ }^{3}$ Departamento de Fitecnia, Universidade Federal do Piauí, Campus Ministro Petrônio Portela, Teresina, Piauí, \\ Brazil \\ Correspondence: Priscila A. Barroso, Laboratório de Melhoramento Genético e Análise de Dados, Universidade \\ Federal do Piauí, Campus Professora Cinobelina Elvas, Bom Jesus, Piauí 64900-000, Brazil. Tel: \\ 55-899-8109-5099. E-mail: pa.barroso@hotmail.com
}

\author{
Received: March 13, $2019 \quad$ Accepted: June 12, $2019 \quad$ Online Published: August 15, 2019 \\ doi:10.5539/jas.v11n13p178 \\ URL: https://doi.org/10.5539/jas.v11n13p178
}

\begin{abstract}
Studies about phenotypic diversity are common in germplasm banks. The inference about this variability must be realized through several methods. The multidimensional scaling is a multivariate technique that has not yet been well explored in plant breeding programs. The objective of this study was to evaluate the phenotypic dispersion of landrace lima bean varieties using the non-metric multidimensional scaling technique (nMDS) based on seed morphology. Seeds of 25 lima bean accessions were characterized based on the morphological descriptors proposed by the International Plant Genetic Resources Institute. Distance matrices between the accessions were estimated based on the qualitative and quantitative variables, in addition to simultaneous analysis of the qualitative and quantitative data, using the Mahalanobis and Gower distances. The distances were represented by non-metric multidimensional scaling. The adjustment level of the nMDS mapping was calculated using Kruskal's Stress. The scaling based on the quantitative and mixed data was efficient to represent the distances of the lima bean accessions in the bidimensional plane presenting Stress less than $20 \%$. Divergent accessions, such as 11, 13, 17 and 25 were identified. The inclusion of qualitative characters provided the best discrimination of the accessions, confirming the importance of the simultaneous character analysis. The nMDS must be used as a complementary technique to those commonly employed in studies of phenotypic diversity in lima beans.
\end{abstract}

Keywords: Phaseolus lunatus L., multivariate analysis, germplasm, plant breeding

\section{Introduction}

Lima bean (Phaseolus lunatus L.) presents rusticity and adaptability to the environment (Vieira, 1992). Its seeds are good sources of nutrients such as proteins, carbohydrates, fibers and minerals (Kathirvel \& Kumudha, 2011). In addition, this crop has an important social aspect in many countries in South America.

In Brazil, more specifically in the Northeast region, the lima bean germplasm used by farmers comes from their own crops and trading between rural communities (Penha et al., 2017). Often, this germplasm is maintained in landrace seed banks, presenting great genetic variability for agronomic traits of interest (Santos et al., 2002). However, Camacho-Pérez et al. (2018) emphasize the reduction of genetic diversity in landrace varieties mainly due to changes in traditional agriculture and market preferences, assuming this as a global problem with high risk to the food security of future generations.

The characterization and the study of the genetic divergence of lima bean seeds allow the knowledge of the germplasm and the development of strategies of conservation and improvement of the species (Valls, 2007). The genetic divergence in lima bean was studied using morphoagronomic and molecular markers (Martinéz-Castillo et al., 2004; Guimarães et al., 2007; Carmo et al., 2013; Silva et al., 2015) using mainly grouping methods. 
According to Silva et al. (2014), several techniques are necessary to make robust inferences about phenotypic variability.

Multidimensional scaling is a multivariate technique that includes a family of spatial distance models as a way of representing proximity data (Carroll \& Arabie, 1980; Davison, 1983). Data of proximity provide information regarding similarity and dissimilarity between individuals as points in the space of low dimension, usually bidimensional or three-dimensional (Scholten \& Caldeira, 1997; Manly, 2004; Borg \& Groenen, 2005).

According to Silva et al. (2014) the scaling is especially useful when the relationship between individuals is unknown, which is very common in germplasm banks, presenting the potential for use in plant breeding programs. Studies of phenotypic diversity among accessions were only found for garlic (Silva et al., 2014) and cocoa (Leal et al., 2008), no records of the use of this technique in lima beans and other important crops were found. The use of bidimensional scaling has been more common in the study of natural populations (Telles et al., 2001; Souza et al., 2015; Higuchi et al., 2018; Silva et al., 2018), in the construction of genetic linkage maps (Preedy \& Hackett, 2016) and not frequent in plant breeding when using molecular data, such as studies of genetic distances between cultivars and varieties of lima bean (P. lunatus) and common bean (P. vulgaris) (Beebe et al, 1995; Nienhuis et al., 1995, Fuente et al., 2012). However, the routine of conventional breeding programs, are mainly based on phenotypic data based on qualitative and quantitative characters, and scaling may be highly applicable for studies of dispersion between accessions.

The objective of this work was to study the phenotypic dispersion of landrace lima bean varieties using the non-metric multidimensional scaling technique (nMDS) based on seed morphological characters.

\section{Method}

\subsection{Plant Material and Characterization}

The experiment was carried out at the Laboratório de Melhoramento e Análise de Dados of the Campus Professora Cinobelina Elvas of the Universidade Federal do Piauí (CPCE/UFPI), located in Bom Jesus-PI, Brazil. The seeds were collected in private properties and fairs of different municipalities, identified and stored in the Germplasm Bank of CPCE/UFPI (Table 1).

Table 1. Accessions of lima bean (Phaseolus Lunatus L) from the Germplasm Bank of the Universidade Federal do Piauí, Bom Jesus-PI, Brazil

\begin{tabular}{lll}
\hline CODE & Popular name & Origin \\
\hline CPCE 01 & Orelha de Vó & Brejo Santo, CE \\
CPCE 02 & Orelha de Vó & Remígio, PB \\
CPCE 03 & Raio de Sol Preta & Brasília, DF \\
CPCE 04 & Raio de Sol Vermelha & Brejo Santo, CE \\
CPCE 05 & Fava Branca & Baixa grande do ribeiro, PI \\
CPCE 06 & Fava Mulatinha & Brejo Santo, CE \\
CPCE 07 & Boca de Moça & Remígio, PB \\
CPCE 08 & Fava moita & Remígio, PB \\
CPCE 09 & Roxinha & Remígio, PB \\
CPCE 10 & Fava Branca & Brejo Santo, CE \\
CPCE 11 & Amarelo Cearense & Remígio, PB \\
CPCE 12 & Rosinha & Remígio, PB \\
CPCE 13 & Non identified* & Mato Grosso \\
CPCE 14 & Branca Gigante & Baixa Grande do Ribeiro, PI \\
CPCE 15 & Branca Gigante & Remígio, PB \\
CPCE 16 & Cana longa & Remígio, PB \\
CPCE 17 & Eucalipto & Remígio, PB \\
CPCE 18 & Branca Pequena & Remígio, PB \\
CPCE 19 & Branca Gigante & Guariba, PI \\
CPCE 20 & Branca Gigante & Tauá, CE \\
CPCE 21 & Orelha de Velho & Brejo Santo, CE \\
CPCE 22 & Fava rajada & Esperança, PB \\
CPCE 23 & Orelha de Vó & Esperança, PB \\
CPCE 24 & Branca Pequena & Cuité, PB \\
CPCE 25 & Cana Longa & Esperança, PB \\
\hline
\end{tabular}


The seeds were characterized according to the following morphological descriptors for Phaseolus lunatus L., recommended by the International Plant Genetic Resources Institute (IPGRI, 2001): Seed Length (SL), Seed Width (SW), Seed thickness (ST), Seed color (SC), patter color of tegument (CPT), second patter color of tegument (SPC), pattern of seed tegument (SPTG), The seeds were also classified according to their size (Mateo Box, cited by Vilhordo et al., 1996) and shape, by the coefficients Length/width (L/W) and thickness/width (T/W), according to Puerta Romero, cited by Vilhordo et al. (1996).

\subsection{Statistical Analysis}

Twenty-five accessions of lima bean were evaluated, in a completely randomized design with 15 replicates, where each seed represented a replicate. Based on the quantitative variables, were calculated the generalized distance of Mahalanobis (Mahalanobis, 1936), obtained through the expression:

$$
\mathrm{D}^{2}{ }_{\mathrm{ii}}{ }^{\prime}=\delta^{\prime} \Psi^{-1} \delta
$$

Where, $\mathrm{D}_{\mathrm{ii}}^{2}=$ Mahalanobis distance among accessions $\mathrm{i}$ and $\mathrm{i}^{\prime} ; \Psi=$ is the matrix of residual variances and covariance; $\delta^{\prime}=\left[d_{1}, d_{2}, \ldots d_{n}\right]$, where $d_{n}=Y_{i j}-Y_{i^{\prime} j}$ and $d_{n}=$ represents the difference between mean of two accessions $i$ and $i$ 'for each evaluated characteristic; $Y_{i j}=$ mean of the $i$-th accession relative to the $j$-th parameter.

A matrix with qualitative data was constructed using Gower's distance (Gower, 1971), employing the equation:

$$
\mathrm{S}_{\mathrm{ij}}=\frac{\sum_{\mathrm{k}=1}^{\mathrm{n}} \mathrm{W}_{\mathrm{ijk}} \mathrm{S}_{\mathrm{ijk}}}{\sum_{\mathrm{k}=1}^{\mathrm{n}} \mathrm{W}_{\mathrm{ijk}}}
$$

Where, $\mathrm{S}_{\mathrm{ij}}$ is the distance between the accessions $\mathrm{i}$ and $\mathrm{j} ; \mathrm{W}_{\mathrm{ijk}}$ is a weight given to the comparison $\mathrm{ijk}$, assigning value 1 for valid comparisons and value 0 for invalid comparisons (when the value of the variable is absent in one or both individuals). $S_{\mathrm{ijk}}$ is the contribution of variable $\mathrm{k}$ in the similarity between individuals $\mathrm{i}$ and $\mathrm{j}$, having values between 0 and 1 . For a nominal variable, if the value of variable $k$ is the same for both individuals, $i$ andj, then $\mathrm{S}_{\mathrm{ijk}}=1$, otherwise, it is equal to 0 . Simultaneous analysis of qualitative and quantitative data was performed on the basis of the two matrices of distance.

It was also applied the non-metric multidimensional scaling (nMDS) for a graphic representation in the bidimensional space of the distance matrices. The analysis of the level of non-fit of the nMDS mapping was calculated using Kruskal's Stress (Kruskal, 1964).

$$
\text { Stress }_{1}=\left[\frac{\sum_{\mathrm{i}=1}^{\mathrm{n}-1} \sum_{\mathrm{j}>1}^{\mathrm{n}}\left(\mathrm{d}_{\mathrm{ij}}-\tilde{\mathrm{d}}_{\mathrm{ij}}\right)^{2}}{\sum_{\mathrm{i}=1}^{\mathrm{n}-1} \sum_{\mathrm{j}>1}^{\mathrm{n}} \tilde{\mathrm{d}}_{\mathrm{ij}}{ }^{2}}\right]^{\frac{1}{2}}
$$

Where, $d_{i j}$ is the distance between the accessions $i$ and $j ; \tilde{d}_{i j}$ is the space distance between the accessions $i$ and $j$.

The Stress values table proposed by Sturrock and Rocha (2000) was used to validate the result obtained with the nMDS solution, comparing the value obtained with the tension value generated from matrices with the same number of objects and the same number of dimensions. All analyses were performed with software $\mathrm{R}$ version 3.0.3 (R Core Team, 2014).

\section{Results and Discussion}

The seed germplasm bank of the UFPI/CPCE, presents a great phenotypic diversity, evidenced by the dispersion represented by multidimensional scaling (Figure 1).

The non-metric multidimensional scaling technique (nMDS) presented the distance between lima bean accesses in the graphical form (Figure 1), in which a large dispersion can be observed for the three representations. Scaling presented $21.77 \%$ of Stress value for qualitative data (Figure 1A), $4.17 \%$ for quantitative data (Figure 1B) and $18.47 \%$ when the matrix distance was used for mixed data (qualitative + quantitative) (Figure 1C). According to the table proposed by Sturrock and Rocha (2000), with $n=25$ accessions and $\mathrm{k}=2$ dimensions, there is a probability $(\mathrm{p}<0.01)$ that the accessions are randomly arranged in bi-dimensional space. The lower the Stress value, the more real is the position of the points in the generated scaling, with little distortion in the data with the reduction of the dimensions (Clarke \& Warwick, 2001).

However, Stress values of up to $20.00 \%$ are acceptable in this type of analysis (Kruskal et al., 1964; Meyer et al., 2004). According to this criterion, the scaling based on the quantitative and mixed data was efficient to represent the distances of the lima bean accessions in the graphic, indicating a good ordering. Thus, through this analysis, it is possible to identify more divergent materials, which contain phenotype of interest for the genetic improvement of the species. In this experiment, the dispersion of accessions based on qualitative data was unsatisfactory. 
Based on the quantitative data, it can be observed that accessions 5, 9, 11, 14, 15 17, 19 and 25 are geographically isolated from the others, and can be considered more divergent. Accession 25 (Cana Longa) from Paraíba state, presented thick seeds, being the only variety classified as full seed. It is important to note that accesses 14, 15 and 19, although belonging to the same variety, known as Branca Gigante, are not close, considering the dimensions of the scaling, also distancing itself from the accession 20, which belongs to the same variety. Accession 20, for example, is closer to accession 01 (Orelha de Vó).

These results show the influence of the sites where the accessions were collected, given the quantitative nature of the variables, the seeds may have been submitted to different edaphoclimatic conditions during their development. In this sense, it can be selected accessions that have characteristics of interest to the breeding program, such as: among the four accessions of Branca gigante, the accessions 14 and 15 from Piauí and Paraiba, respectively, present larger and wider seeds, which would increase production indexes. However, the accessions 19 and 20 present smaller but thicker seeds, which could be desirable for consumers because of their similarity to common beans. Using other multivariate techniques, Carmo et al. (2013) also identified divergent accessions mainly for lima bean grain diameter and thickness.

The other accessions can be grouped since they are closer in the bi-dimensional plane, sharing similarities for the quantitative characters of seeds. It can be highlighted that the proximity of the accessions 23 (Orelha de Vó) and 24 (Branca Pequena), both collected in the state of Paraíba, have a similar form, based on the J coefficient. A larger group could be represented by the accessions $4,8,10,18,21,22$ that present average length ranging from $11.46 \mathrm{~mm}$ (04) to $13.61 \mathrm{~mm}$ (22), average width between $8.61 \mathrm{~mm}(04)$ to $9.89 \mathrm{~mm}$ (21), classified as medium to large seeds (Table 2).

The estimated distances for the mixed data, resulted in a greater dispersion of the accessions, confirming the phenotypic diversity in the lima bean seeds given by the inclusion of the qualitative characters (Figure 1C). According to Vargas et al. (2003) the seeds of this species exhibit a great variety of color and size and these characteristics are used as a criterion to explain the origin and the genetic diversity. This fact can be observed when analyzing the representation of the distances between accessions 1, 2 and 23, all belonging to the variety known as Orelha de Vó when including the qualitative variables, these accessions were close in the bidimensional plane, different from what was observed when considering only quantitative data. Thus, multidimensional scaling for mixed data, with acceptable Stress level, may better discriminate the genotypes desirable for selection. Some authors, although did not use multidimensional scaling, have verified the importance of using mixed data, from Gower's distance to analyze the genetic diversity among accessions (Sudré et al., 2010; Oliveira et al., 2015; Mesquita et al., 2016; Upadhyaya et al., 2017).

Again, based on the mixed data, accessions 25 and 17 were more divergent, and also did the accession 13 . Despite the randomness of the dispersion based on the qualitative data, the divergence for accessions 13 (unidentified variety) and 17 (Eucalipto) is also observed in Figure 1A. Both accessions are unique specimens in the germplasm bank, differing mainly for seed color, pattern color and second pattern color (Table 2). The color of the seed coat is a factor that can contribute to the good commercialization of the product and this will depend on the preference of the consumers in the different regions (Guimarães et al., 2007). Accession 25 (Cana Longa) presents traits of interest for plant breeding such as normal-sized grains and classified as full. Nienhuis et al. (1995), using scaling based on RAPD markers, grouped lima bean accessions, made an association with the phenotypic data, and verified that these accessions were similar in size and color, emphasizing once again the importance of the qualitative variables.

The success of a breeding program, among other factors, depends on the evaluation carried out with the accesses of the genetic diversity existing in the active germplasm banks in order to determine the potential of higher potential materials that meet the demand of the producer and consumer market. Knowledge about the phenotypic relationship between accessions of germplasm banks may reveal sources of desirable traits for the definition of strategies, planning and optimization of lima-bean breeding programs.

The study of these relationships, as verified in this work, can be performed through nMDS, as a complementary technique to those commonly used, since there may be disagreement between multivariate methods (Carmo et al., 2013). Silva et al. (2014) reported that the representation of the phenotypic distance of garlic cultivars by multidimensional scaling was more effective than the UPGMA clustering method. Therefore, it is necessary to use several methods and the scaling is an option that must be considered, especially when combined with the simultaneous analysis of qualitative and quantitative characters. 

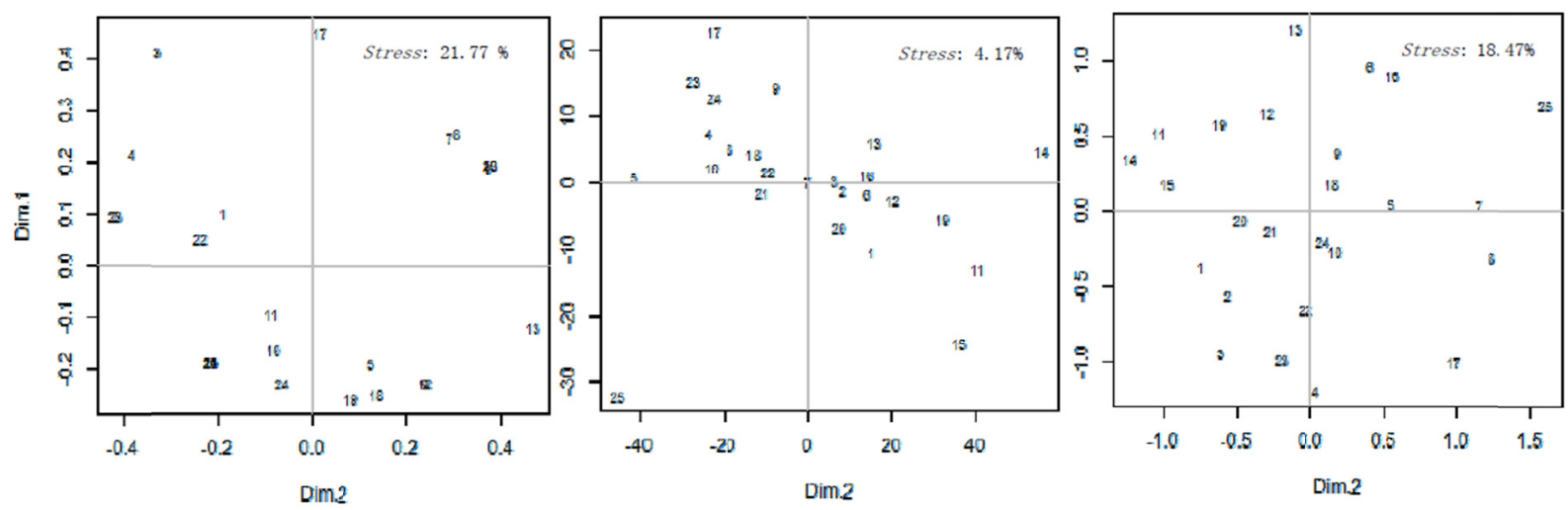

Figure 1. Graphical dispersion of 25 lima bean (Phaseolus lunatus L.) accessions through multidimensional scaling based on qualitative (A), quantitative (B) and mixed (C) data

Table 2. Quantitative and qualitative morphological characteristics of lima bean (Phaseolus lunatus L.)

\begin{tabular}{|c|c|c|c|c|c|c|c|c|c|c|c|c|}
\hline Acession & SL & SW & ST & $\mathrm{J}$ & $\mathrm{H}$ & $\mathrm{SC}$ & $\mathrm{CPT}$ & SPC & PSTG & SIZE & SHAP1 & SHAP2 \\
\hline СРCE 01 & 16.29 & 12.05 & 6.39 & 1.36 & 0.53 & White & Absent & Black & Pattern 7 & Large & Spherical & Flat \\
\hline CPCE 02 & 16.25 & 10.68 & 5.85 & 1.52 & 0.55 & White & Absent & Black & Pattern 6 & Large & Elliptical & Flat \\
\hline CPCE 03 & 15.69 & 10.84 & 5.89 & 1.46 & 0.55 & Gray & Black & Black & Pattern 6 & Large & Elliptical & Flat \\
\hline CPCE 04 & 11.46 & 8.61 & 5.78 & 1.33 & 0.67 & White & Red-Purple & Brown & Pattern 6 & Large & Spherical & Flat \\
\hline CPCE 05 & 9.87 & 8.31 & 6.36 & 1.19 & 0.77 & White & Absent & Absent & Absent & Normal & Spherical & Semi-full \\
\hline CPCE 06 & 16.63 & 11.24 & 5.89 & 1.48 & 0.53 & Light-Gray & Dark-Brown & Absent & Pattern 1 & Normal & Elliptical & Flat \\
\hline CPCE 07 & 15.01 & 10.26 & 6.02 & 1.47 & 0.59 & Gray & Red & Red & Pattern 5 & Medium & Elliptical & Flat \\
\hline CPCE 08 & 12.16 & 9.09 & 5.92 & 1.34 & 0.65 & Gray & Light-Brown/Orange & Brown & Pattern 3 & Medium & Spherical & Flat \\
\hline CPCE 09 & 13.21 & 9.61 & 5.05 & 1.37 & 0.53 & Red-Purple & Absent & Absent & Absent & Medium & Spherical & Flat \\
\hline CPCE 10 & 12.19 & 8.58 & 6.07 & 1.42 & 0.75 & White & Absent & Absent & Absent & Normal & Elliptical & Semi-full \\
\hline CPCE 11 & 18.99 & 13.98 & 6.65 & 1.36 & 0.47 & Light-Brown & Absent & Absent & Absent & Large & Spherical & Flat \\
\hline CPCE 12 & 17.11 & 11.89 & 5.83 & 1.45 & 0.49 & Orange & Absent & Absent & Absent & Medium & Elliptical & Flat \\
\hline CPCE 13 & 15.97 & 11.69 & 5.52 & 1.38 & 0.48 & Light-Brown & Light-Brown/Orange & Absent & Absent & Medium & Spherical & Semi-full \\
\hline CPCE 14 & 20.43 & 14.06 & 5.09 & 1.46 & 0.36 & White & Absent & Absent & Absent & Large & Elliptical & Flat \\
\hline CPCE 15 & 20.13 & 13.00 & 6.95 & 1.55 & 0.54 & White & Absent & Absent & Pattern 1 & Large & Elliptical & Flat \\
\hline CPCE 16 & 16.96 & 10.85 & 5.71 & 1.57 & 0.53 & Light-Brown & Dark-Brown & Absent & Pattern 4 & Normal & Elliptical & Flat \\
\hline CPCE 17 & 11.94 & 7.93 & 5.44 & 1.50 & 0.69 & Light-Brown & Dark-Brown & Black & Pattern 7 & Normal & Elliptical & Flat \\
\hline CPCE 18 & 12.94 & 9.63 & 5.90 & 1.34 & 0.61 & White & Absent & Absent & Pattern 7 & Medium & Spherical & Semi-full \\
\hline CPCE 19 & 18.11 & 13.36 & 6.06 & 1.38 & 0.46 & White & Absent & Absent & Absent & Small & Spherical & Flat \\
\hline CPCE 20 & 16.50 & 10.61 & 6.19 & 1.56 & 0.58 & White & Absent & Absent & Absent & Large & Elliptical & Flat \\
\hline CPCE 21 & 13.45 & 9.89 & 6.32 & 1.36 & 0.64 & White & Absent & Absent & Absent & Large & Elliptical & Flat \\
\hline CPCE 22 & 13.61 & 9.69 & 6.11 & 1.40 & 0.63 & White & Red-Purple & Absent & Pattern 5 & Large & Spherical & Flat \\
\hline CPCE 23 & 10.93 & 8.13 & 5.27 & 1.35 & 0.65 & White & Black & Absent & Pattern 6 & Large & Spherical & Flat \\
\hline CPCE 24 & 11.64 & 8.51 & 5.35 & 1.37 & 0.63 & White & Light-Brown/Orange & Red-Purple & Pattern 3 & Medium & Spherical & Semi-full \\
\hline CPCE 25 & 11.20 & 8.07 & 8.41 & 1.39 & 1.11 & Gray & Light-Brown/Orange & Red-Purple & Pattern 3 & Normal & Spherical & Cheia \\
\hline
\end{tabular}

Note. $\mathrm{SL}=$ Seed Length, $\mathrm{SW}=$ Seed Width, $\mathrm{ST}=$ Seed thickness, $\mathrm{J}=$ coefficients Length/width, $\mathrm{H}=$ Coefficients thickness/width, $\mathrm{SC}=$ Seed color $(\mathrm{SC}) ; \mathrm{CPT}=$ Patter color of tegument; $\mathrm{SPC}=$ Second patter color of tegument; PSTG $=$ Pattern of seed tegument.

\section{Conclusions}

The proposed statistical analysis was useful to evaluate the diversity among lima-bean accessions of the CPCE/UFPI germplasm bank. Based on the technique of multidimensional non-metric scheduling, it was possible to identify the accessions $11,13,17$ and 25 as the most divergent. These accessions have the potential to be used as parents in breeding programs of this species. New acquisitions of germplasm, together with the amplification of morphoagronomic characteristics, with evaluations using molecular markers, cytogenetic and 
palynological techniques, will contribute qualitatively and quantitatively to the conservation and selection of new genotypes with the adaptive potential of the southern edaphic conditions of the state of Piauí-Brazil.

\section{References}

Beebe, S. E., Ochoa, I., Skroch, P., Nienhuis, J., \& Tivang, J. (1995). Genetic diversity among common bean breeding lines developed for Central America. Crop Science, 35(4), 1178-1183. https://doi.org/10.2135/ cropsci1995.0011183X003500040045x

Borg, I., \& Groenen, P. J. F. (2005). Modern multidimensional scaling: Theory and applications (2nd ed.). Springer, New York, NY, USA. https://doi.org/10.1007/0-387-28981-X

Camacho-Pérez, L., Martínez-Castillo, J., Mijangos-Cortes, J. O., Ferrer-Ortega, M. M., Baudoin, J. P., \& Andueza-Noh, R. H. (2018). Genetic structure of lima bean (Phaseolus lunatus L.) landraces grown in the Mayan area. Genetic Resources and Crop Evolution, 65(1), 229-241. https://doi.org/10.1007/ s10722-017-0525-1

Carmo, M. D. S., Gomes, R. L. F., de Almeida Lopes, Â. C., da Penha, J. S., Gomes, S. O., \& de Assunção Filho, J. R. (2013). Variabilidade genética em subamostras de feijão-fava de crescimento determinado. Crop Breeding and Applied Biotechnology, 13(3), 158-164. https://doi.org/10.1590/S1984-70332013000300002

Carroll, J. D., \& Arabie, P. (1980). Multidimensional scaling. Annual Review of Psychology, 31, 607-649. https://doi.org/10.1146/annurev.ps.31.020180.003135

Clarke K. R., \& Warwick R. M. (2001). Change in marine communities: An approach to statistical analysis and interpretation (2nd ed.). Plymouth, UK: Primer-E Ltd.

Davison, M. L. (1983). Multidimensional scaling. New York, NY: John Wiley \& Sons.

Fuente, M., López-Pedrouso, M., Alonso, J., Santalla, M., De Ron, A. M., Álvarez, G., \& Zapata, C. (2012). In-depth characterization of the phaseolin protein diversity of common bean (Phaseolus vulgaris L.) based on two-dimensional electrophoresis and mass spectrometry. Food Technology and Biotechnology, 50(3), $315-325$.

Gower, J. C. (1971). A general coefficient of similarity and some of its properties. Biometrics, 27(4), 857-871. https://doi.org/10.2307/2528823

Guimarães, W. N., Martins, L. S., Silva, E. F., Ferraz, G. M. G., \& Oliveira, F. J. (2007). Caracterização morfológica e molecular de acessos de feijão-fava (Phaseolus lunatus L.). Revista Brasileira de Engenharia Agrícola e Ambiental, 11(1), 37-45.

Higuchi, P., da Silva, A. C., Rodrigues Spiazzi, F., Negrini, M., Rafaeli Neto, S. L., Bento, M. A., \& Leonardo da Silva, A. (2018). Elementos da paisagem como fonte de heterogeneidade florístico-estrutural do componente arbóreo em área de floresta ombrófila mista. Ciência Florestal, 28(2), 661-673. https://doi.org/10.5902/1980509832061

IPGRI (International Plant Genetic Resources Institute). (2001). Descritores para Phaseolus lunatus (feijão espadinho) (p. 51). Rome: IPGRI.

Kathirvel, P., \& Kumudha, P. (2011). A comparative study on the chemical composition of wild and cultivated germplasm of Phaseolus lunatus L. International Journal of Applied Biology and Pharmaceutical Technology, 2(4), 296-305.

Kruskal, J. B. (1964). Multidimensional scaling by optimizing goodness of fit to a nonmetric hypothesis. Psychometrika, 29(1), 1-27. https://doi.org/10.1007/BF02289565

Leal, J. B., dos Santos, L. M., dos Santos, C. A. P., Pires, J. L., Ahnert, D., \& Carrêa, R. X. (2008). Diversidade genética entre acessos de cacau de fazendas e de banco de germoplasma na Bahia. Pesquisa Agropecuária Brasileira, 43(7), 851-858. https://doi.org/10.1590/S0100-204X2008000700009

Mahalanobis, P. C. (1936). On the generalized distance in statistics. Journal of Genetics, 41, 159-193.

Manly, B. F. J. (2004). Multivariate Statistical Methods: A Primer (3rd ed.). London, UK: Chapman \& Hall. https://doi.org/10.1201/b16974

Martínez-Castillo, J., Zizumbo-Villarreal, D., Perales-Rivera, H., \& Colunga-Garcíamarin, P. (2004). Intraspecific diversity and morpho-phenological Variation in Phaseolus lunatus L. from the Yucatan Peninsula, Mexico. Economic Botany, 58(3), 354-380. https://doi.org/10.1663/0013-0001(2004)058[0354: IDAMVI]2.0.CO;2 
Mesquita, J. U. C. P., do Rêgo, E. R., da Silva, A. R., da Silva Neto, J. J. E., Cavalcante, L. C., \& do Rêgo, M. I. M. (2016). Multivariate analysis of the genetic divergence among populations of ornamental pepper (Capsicum annuum L.). African Journal of Agricultural Research, 11(42), 4189-4194. https://doi.org/ 10.5897/AJAR2016.11671

Meyer, A. D. S., Garcia, A. A. F., Souza, A. P. D., \& Souza Jr, C. L. D. (2004). Comparison of similarity coefficients used for cluster analysis with dominant markers in maize (Zea mays L.). Genetics and Molecular Biology, 27(1), 83-91. https://doi.org/10.1590/S1415-47572004000100014

Nienhuis, J., Tivang, J., Skroch, P., \& dos Santos, J. B. (1995). Genetic relationships among cultivars and landraces of lima bean (Phaseolus lunatus L.) as measured by RAPD markers. Journal of the American Society for Horticultural Science, 120(2), 300-306. https://doi.org/10.21273/JASHS.120.2.300

Oliveira, E. J., Oliveira Filho, O. S., \& Santos, V. S. (2015). Classification of cassava genotypes based on qualitative and quantitative data. Genetics and Molecular Research, 14(1), 906-924. https://doi.org/10.4238/ 2015.February.2.14

Penha, J. S., Lopes, A. C. A., Gomes, R. L. F., Pinheiro, J. B., Assunção Filho, J. R., Silvestre, E. A., ... Martínez-Castillo, J. (2017). Estimation of natural outcrossing rate and genetic diversity in Lima bean (Phaseolus lunatus L. var. lunatus) from Brazil using SSR markers: Implications for conservation and breeding. Genetic Resources and Crop Evolution, 64(6), 1355-1364. https://doi.org/10.1007/s10722016-0441-9

Preedy, K. F., \& Hackett, C. A. (2016). A rapid marker ordering approach for high-density genetic linkage maps in experimental autotetraploid populations using multidimensional scaling. Theoretical and Applied Genetics, 129(11), 2117-2132. https://doi.org/10.1007/s00122-016-2761-8

$\mathrm{R}$ Core Team (2014). R: A language and environment for statistical computing. R Foundation for Statistical Computing, Vienna, Austria. Retrieved from https://www.R-project.org

Santos, D., Corlett, F. M. F., Mendes, J. E. M. F., \& Júnior, J. S. A. W. (2002). Produtividade e morfologia de vagens e sementes de variedades de fava no Estado da Paraíba. Pesquisa Agropecuária Brasileira, 37(10), 1407-1412. https://doi.org/10.1590/S0100-204X2002001000008

Scholten, M., \& Caldeira, P. Z. (1997). O senso do escalonamento multidimensional. Análise Psicológica, 15(1), 63-85.

Silva, A. R. D., Cecon, P. R., Dias, C. T. D. S., Puiatti, M., Finger, F. L., \& Carneiro, A. P. S. (2014). Morphological phenotypic dispersion of garlic cultivars by cluster analysis and multidimensional scaling. Scientia Agricola, 71(1), 38-43. https://doi.org/10.1590/S0103-90162014000100005

Silva, R. M., Reis, Â. C. A., \& Mehlig, U. (2018). Diversity and dominance patterns in Amazon coast dune forest island tree communities. Plant Ecology, 219(3), 343-357. https://doi.org/10.1007/s11258-018-0799-1

Silva, V. B., Gomes, R. L. F, Lopes, Â. C. A., Dias, C. T. S., \& Silva, R. N. O. (2015). Genetic diversity and promising crosses indication in lima bean (Phaseolus lunatus) accessions. Semina: Ciências Agrárias, 36(2), 683-692. https://doi.org/10.5433/1679-0359.2015v36n2p683

Souza, K., Souza, C. D., Rosa, M. D., Cruz, A. P., Lima, C. L., Silva, J. D., ... Higuchi, P. (2015). Estrutura e estratégias de dispersão do componente arbóreo de uma floresta subtropical ao longo de uma topossequência no Alto-Uruguai. Scientia Forestalis, 43(106), 321-332.

Sturrock, K., \& Rocha, J. (2000). A multidimensional scaling stress evaluation table. Field Methods, 12(1), 49-60. https://doi.org/10.1177/1525822X0001200104

Sudré, C. P., Gonçalves, L. S. A., Rodrigues, R., Amaral Júnior, A. D., Riva-Souza, E. M., \& Bento, C. D. S. (2010). Genetic variability in domesticated Capsicum spp. as assessed by morphological and agronomic data in mixed statistical analysis. Genetics and Molecular Research, 9(1), 283-294. https://doi.org/ 10.4238/vol9-1gmr698

Telles, M. P. D. C., Silva, R. S. M., Chaves, L. J., Coelho, A. S. G., \& Diniz Filho, J. A. F. (2001). Divergência entre subpopulações de cagaiteira (Eugenia dysenterica) em resposta a padrões edáficos e distribuição espacial. Pesquisa Agropecuária Brasileira, 36(11), 1387-1394. https://doi.org/10.1590/S0100-204X2001 001100009 
Upadhyaya, H. D., Reddy, K. N., Vetriventhan, M., Ahmed, M. I., Krishna, G. M., Reddy, M. T., \& Singh, S. K. (2017). Sorghum germplasm from West and Central Africa maintained in the ICRISAT genebank: Status, gaps, and diversity. The Crop Journal, 5(6), 518-532. https://doi.org/10.1016/j.cj.2017.07.002

Valls, J. F. M. (2007). Caracterização de recursos genéticos vegetais. In L. L. Nass (Ed.), Recursos genéticos vegetais (pp. 283-305). Brasília: Embrapa Recursos Genéticos e Biotecnologia.

Vargas, E. M., Castro, E., Macaya, G., \& Rocha, O. J. (2003). Variación del tamaño de frutos y semillas en 38 poblaciones silvestres de Phaseolus lunatus (Fabaceae) del Valle Central de Costa Rica. Revista de Biología Tropical, 51(3-4), 707-724.

Vieira, R. F. (1992). A cultura do feijão-fava. Informe Agropecuário, Belo Horizonte, 16, 30-37.

Vilhordo, B. W., Araújo, R. S., Rava, C. A., Stone, L. F., \& M. J. de O. Morfologia. (1996). In R. S. Araújo, C. A. Rava, L. F. Stone, \& M. J. de O. Zimmerman (Eds.), Cultura do feijoeiro comum no Brasil (pp. 71-99). Piracicaba: Potafos.

\section{Copyrights}

Copyright for this article is retained by the author(s), with first publication rights granted to the journal.

This is an open-access article distributed under the terms and conditions of the Creative Commons Attribution license (http://creativecommons.org/licenses/by/4.0/). 